\title{
Carbon dioxide from fossil fuels
}

\section{Adapting to uncertainty}

\author{
Kan Chen, Richard C. Winter and Michael K. Bergman
}

If present scientific information is reasonable, the world is likely to experience noticeable global warming by the beginning of the next century if high annual growth rates of fossil fuel energy use continue. Only with optimistic assumptions and low growth rates will carbon-dioxide-induced temperature increases be held below $2^{\circ} \mathrm{C}$ or so over the next century. Conservation, flexible energy choices and control options could lessen the potential effects of carbon dioxide. Though perhaps impractical from the standpoint of costs and efficiency losses, large coastal centralized facilities would be the most amenable to carbon dioxide control and disposal. Yet no country can control carbon dioxide levels unilaterally. The USA, however, which currently contributes over a quarter of all fossil fuel carbon dioxide emissions and possesses a quarter of the world's coal resources, could provide a much needed role in leadership, research and education.

K. Chen is Professor of Electrical and Computer Engineering and Director of the Program in Technology Assessment at the University of Michigan, Room 4520, East Engineering Building, Ann Arbor, MI continued on $p 319$
Since the beginning of the Industrial Revolution the large-scale combustion of fossil fuels has been releasing carbon dioxide $\left(\mathrm{CO}_{2}\right)$ into the atmosphere. The carbon dioxide content of the atmosphere has risen from about 270 to $290 \mathrm{ppm}$ (parts per million) in 1860 , to about $330 \mathrm{ppm}$ at present. About half of the fossil fuel $\mathrm{CO}_{2}$ released each year remains in the atmosphere, while the rest is thought to go into the oceans and possibly the biosphere. The significance of this increase in atmospheric $\mathrm{CO}_{2}$ is due to the 'greenhouse effect', which could act to warm the earth's surface sufficiently to cause worldwide climatic and environmental changes. Because of the apparent correlation between the rate of fossil fuel use and increasing levels of atmospheric $\mathrm{CO}_{2}$, the world may be caught in an 'environmental vice': between radioactive nuclear waste and $\mathrm{CO}_{2}$ effects from combusting fossil fuels. ${ }^{1} \mathrm{~A}$ further complication is that some nations or regions may benefit as a result of $\mathrm{CO}_{2}$ effects while others may lose.

Little attention is being paid to what might be done and by whom if the effects become significant, and in addition, what else should be done now besides scientific research. This article proposes some ideas about what can be done from a policy-making perspective if the $\mathrm{CO}_{2}$ effects occur, and how, in addition, we can deal now with the uncertainties. We will also address questions concerning the potential for control of $\mathrm{CO}_{2}$ emissions drawing upon current work in longrange coal based energy technology assessment. ${ }^{2}$

\section{Some potential consequences}

Atmospheric $\mathrm{CO}_{2}$ levels are increasing and there is general agreement that continued increases may raise the average temperature of the earth's surface. ${ }^{3}$ While the magnitude of increase is highly uncertain, it is expected to be greater at the higher latitudes than at the equator. ${ }^{4}$ Evidence also suggests that net global precipitation increases as average temperatures rise. ${ }^{5}$ Elevated temperatures may also cause changes in wind and ocean current patterns ${ }^{6}$ and shifts in regional precipitation. $^{7}$ 
continued from $p 318$

48109, USA. R.C. Winter is with the Urban and Regional Planning Program at the University of Michigan, Ann Arbor, MI 48109. M.K. Bergman is Project Officer for the National Coal Technology Assessment Program at the Industrial Environmental Research Laboratory, US Environmental Protection Agency, Research Triangle Park, NC 27711. USA.

We gratefully acknowledge the valuable assistance of D. Gates and O.W. Markley for their consultation on this project. We thank $E$. Hall for providing the $\mathrm{CO}_{2}$ conversion figures. A. Albanese contributed greatly to the section on control technology. Other individuals who have contributed to our research include E.G. Bobalek, T. DeHudy, R.M. Dykes, R. Letcher, and also the attendees at our December 1978 forum on carbon dioxide. Special thanks are offered to T.G. Hereford and J. Shorett for editorial assistance on the manuscript. Comments by an anonymous reviewer are acknowledged for many improvements in the paper. Work was supported by EPA Contract No 68-02-2672 to Battelle Columbus Laboratories and the University of Michigan.

1 D. Gates, personal communication, 1978.

2 The Coal Technology Assessment Program, sponsored by the US Environmental Protection Agency, is directed toward identifying. understanding and analysing the potential impacts in deploying conventional and advanced coal based energy technologies.

${ }^{3}$ Gates, op cit, Ref 1, B. Bolin, Annual Review of Energy, Vol 2, 1977, pp 204218 , C.D. Keeling and R.B. Bacastow, in Geophysics Study Committee, National Research Council, Energy and Climate, National Academy of Sciences, Washington, DC, 1977, p 74, J.H. Mercer, Nature, Vol 271, 1978, p 321, S. Manabe and R.T. Wetherald, Journal of Atmospheric Sciences, Vol 32, 1975, pp 3-15 and S.H. Schneider, Journal of Atmospheric Sciences, Vol 32, 1975, p 2060. Schneider, reviewing a number of different models, indicates a range of 1.5$3.5^{\circ} \mathrm{C}$. All models use simplifying assumptions.

${ }^{4}$ Gates, op cit, Ref 1, Mercer, op cit, Ref 3. Manabe and Wetherald, op cit, Ref 3. and Schneider, op cit, Ref 3.

5 Gates, op cit, Ref 1, Manabe and Wetherald, op cit, Ref 3, R.G. Barry, paper presented at US Energy Research and Development Administration Miami Workshop on Environmental Effects of Carbon Dioxide from Fossil Fuel continued on $p 320$
Regional shifts in temperature and precipitation may have significant consequences for agriculture. For example, under warmer or dryer conditions, decreased yields have been noted for prevalent strains of corn and rice, with increased yields for wheat. ${ }^{8}$ Relatively small changes in temperature can have major impacts on agricultural productivity. A rule of thumb used by agronomists is that a $1^{\circ} \mathrm{C}$ change in temperature results in about a 10 day change in the length of the growing season. ${ }^{9}$ Such shifts could have a major impact on the relative contributions of major world food supply regions. Lower soil fertility and an absence of the infrastructure necessary for large-scale production and distribution could occur in areas newly opened for agricultural development. These factors could lead to disrupted international food markets, food shortages, rationing, and perhaps famine. Alternatively, a wetter and warmer climate could mean net increase in global agricultural production in the long term.

Even in the short term there could be an impact of climatic transition on the fragile global food supply network, such as that experienced in 1971 and 1972, when temperature fell as much as $0.8^{\circ} \mathrm{C}$ below normal in the Northern Hemisphere. ${ }^{10}$ This deviation contributed to devastating monsoons, drought, and a disappointing rice crop in southeast Asia; wheat crop failures in the USSR; poor crops in India; continued drought in northern Africa; and a poor anchovy catch off the coast of Peru. ${ }^{11}$ Famine was commonplace in India and Africa, and food prices rose sharply in the USA.

Changes in regional hydrology, such as less precipitation and increased evaporation in areas with limited water supplies, ${ }^{12}$ eg western USA, and rising sea levels due to melting of polar ice, ${ }^{13}$ are further effects which may arise from increased atmospheric $\mathrm{CO}_{2}$ Shoreline development, recreation, agriculture, water-intensive energy and industrial facilities, and resident populations could be adversely affected. ${ }^{14}$

Shorter-term temperature rises also may be of grave concern if thresholds exist in the global carbon balance. For example, in the late Mesozoic, deep oceanic waters may have been triggered into releasing vast amounts of $\mathrm{CO}_{2}$ into the atmosphere in a positive feedback between climatic warming and $\mathrm{CO}_{2}$ expulsion. ${ }^{15}$ Minor percentage shifts in carbon held in detritus pools could also result in large releases of $\mathrm{CO}_{2}{ }^{16}$ The possibility that relatively small temperature changes may create positive feedback effects dictates caution in projecting time horizons for the possible effects of $\mathrm{CO}_{2}$.

\section{Scientific analysis and uncertainties}

The current annual rate of fossil-fuel-induced $\mathrm{CO}_{2}$ release to the atmosphere is about $5 \times 10^{9}$ tonnes of carbon $\left(10^{15} \mathrm{~g}\right.$ of carbon equivalent), or about $2 \mathrm{ppm}$ of equivalent atmospheric concentration. ${ }^{17}$ The residence time of $\mathrm{CO}_{2}$ in the troposphere is about 2 years. However, unlike particulate matter and tropospheric aerosols, the $\mathrm{CO}_{2}$ exchange rate between the atmosphere and the ocean is very slow and if a large amount of $\mathrm{CO}_{2}$ is added relatively quickly to the atmosphere it will take hundreds or thousands of years before this $\mathrm{CO}_{2}$ enters the oceans and the atmospheric concentration returns to its former level. ${ }^{18}$ The present level of $\mathrm{CO}_{2}$ in the atmosphere is between $330 \mathrm{ppm}$ and $340 \mathrm{ppm},{ }^{19}$ with the variation ascribed to 'pulses' in $\mathrm{CO}_{2}$ uptake due to major plant growing 
Source: Based on table presented by O.W. Markley et al, Ref 12, after revision comments by R. Wetherald, R. Ramanathan, W.W. Kellogg, and J.M. Mitchell. Further revised by D. Gates who lowered the optimistic estimates.

\section{continued from $p 319$}

Combustion, Miami Beach, FL, March 1978, and W.W. Kellogg, in J. Gribbin, ed, Climatic Changes, Cambridge University Press, Cambridge, 1978.

${ }^{6}$ Bolin, op cit, Ref 3

${ }^{7}$ Kellog, op cit, Ref 5.

${ }^{8} \mathrm{~W}$. Bach, in J. Williams, ed, Carbon Dioxide, Climate and Society, Pergamon, Oxford, 1978, pp 153-158.

${ }^{9}$ C.E. Cooper, Foreign Affairs, Vol 56 , 1978, p 512.

${ }^{10}$ B. Bolin, op cit, Ref 3, p 203. See Figure 3.

11 D. Shapley, Science, Vol 195, 1977, p 377 and W. Bach, in Williams, op cit, Ref 8, p 161.

${ }^{12}$ O.W. Markley, A.L. Webre, R.C. Carlson and B.R. Holt, Socio-political Impacts of Carbon Dioxide Buildup in the Atmosphere Due to Fossil Fuel Combustion, discussion draft prepared for the US Energy Research and Development Administration, 1977, p 35.

${ }^{13}$ Mercer, op cit, Ref 3 and R.H. Thomas,

T.J.O. Sanderson and K.E. Rose, Nature, Vol 277, 1979, p 355

${ }^{14}$ S.H. Schneider and K. Chen, paper to AAAS meeting, Annapolis, MD, 1979, as reported in Technology Review. March/April 1979, p 72

15 D.M. McLean, Science, Vot 201, 1978, p 405.

${ }^{16}$ Gates, op cit, Ref 1 and W.H. Schlesinger, Annual Review of Ecological Systems, Vol 8, 1977, pp 51-73.

${ }_{17}$ C.D. Keeling, R.B. Bacastow, A.E. Bainbridge, C.A. Ekdahl, P.R. Guenther, L.S. Waterman and J.F.S. Chin, Tel/us, Vol 28, 1976, p 538

${ }^{18} \mathrm{~A}$. McLellan, Changes in the Global Energy Balance, IES Report 31, Institute for Environmental Studies, University of Wisconsin-Madison, 1974, p 12, C.E. Cooper, op cit, Ref 9, p 510, C.E. Baes, H.E. Goeller, J.I. OIsen and R.M. Rotty, American Scientist, Vol 65, 1965, p 316 , Table 1, and Geophysics Study Committee, op cit, Ref 3, pp 2-3.

19 Keeling et al, op cit, Ref 17

${ }^{20}$ G.M. Woodwell, R.H. Whittaker, W.A. Reiners, G.E. Likens, C.C. Delwiche and D.B. Botkin, Science, Vol 199, 1978, p 142.

${ }^{21} \mathrm{H}$. Oeschger and $U$. Siegenthater, in Williams, op cit, Ref 8, pp 53-54. While the authors cite vegetational cycles as probably the major cause of observed continued on $p 321$
Table 1. Range of $\mathrm{CO}_{2}$-induced temperature rise $\left({ }^{\circ} \mathrm{C}\right)$.

\begin{tabular}{|c|c|c|c|c|c|c|}
\hline \multirow[t]{2}{*}{$\begin{array}{l}\text { Atmospheric } \\
\mathrm{CO}_{2} \text { lovel }\end{array}$} & \multicolumn{2}{|c|}{$\begin{array}{l}\text { Low latitude } \\
\left(0^{\circ}-5^{\circ}\right)\end{array}$} & \multicolumn{2}{|l|}{ Average } & \multicolumn{2}{|c|}{$\begin{array}{l}\text { High latitude } \\
\left(80^{\circ}-90^{\circ}\right)\end{array}$} \\
\hline & Optimistic & Pessimistic & Optimistic & Pessimistic & Optimistic & Pessimisti \\
\hline $\begin{array}{l}\text { level } \\
4 \times \text { preindustrial }\end{array}$ & 0.8 & 2.4 & 1.5 & 2.9 & 3.6 & 11 \\
\hline $\begin{array}{l}\text { level } \\
6 \times \text { preindustrial }\end{array}$ & 1.9 & 4.8 & 2.9 & 5.8 & 7.5 & 18 \\
\hline level & 2.8 & 6.0 & 4.1 & 7.5 & 9.0 & 20 \\
\hline
\end{tabular}

seasons ${ }^{20}$ or other mechanisms. ${ }^{21}$ Pre-industrial $\mathrm{CO}_{2}$ levels (c 1860) are commonly held to be about $290 \mathrm{ppm},{ }^{22}$ though recent reports have suggested levels as low as $268 \mathrm{ppm}$ to $270 \mathrm{ppm} .{ }^{23}$ From 1958 to 1968 observed annual atmospheric $\mathrm{CO}_{2}$ increases averaged $0.75 \mathrm{ppm}$ and exceeded $1 \mathrm{ppm}$ by $1974 .{ }^{24}$ The disparity between observed increases and known $\mathrm{CO}_{2}$ releases has led to controversy about whether the biosphere is a source or sink for carbon dioxide, and if it is a source, where the other sinks are that explain this disparity. ${ }^{25}$

The magnitude of future $\mathrm{CO}_{2}$-induced temperature increases is a function of three variables: ${ }^{26}$

fluxes, sources and sinks in the global carbon cycle;

$\mathrm{CO}_{2}$-induced temperature effects;

future $\mathrm{CO}_{2}$ releases.

\section{The global carbon cycle}

Carbon is cycled between terrestrial, atmospheric, and oceanic reservoirs. ${ }^{27}$ For our purposes, stored carbon in fossil fuels is treated as an exogenous variable. Whether the terrestrial reservoir is a net global source or sink for $\mathrm{CO}_{2}$ is a very controversial question, ${ }^{28}$ as are questions about ocean uptake and mixing between the surface (through the thermocline) and the deep ocean. ${ }^{29}$ Release of $\mathrm{CO}_{2}$ due to changes in land biota is implicitly incorporated in our range analysis for the terrestrial carbon reservoir.

\section{Temperature effects}

Models exist for predicting average global temperature rise for a given increase in $\mathrm{CO}_{2}$ alone. While the relationships between increase in atmospheric $\mathrm{CO}_{2}$ and temperature change are complex, data from Manabe and Wetherald's general circulation model ${ }^{30}$ indicate that a doubling of atmospheric $\mathrm{CO}_{2}$ concentration would lead to an average global temperature increase of about $2.5^{\circ} \mathrm{C} .{ }^{31}$ However, additional mechanisms complicate the relationship between increases in atmospheric $\mathrm{CO}_{2}$ and temperature change. ${ }^{32}$ As a result, our choice of temperature ranges for a given doubling of atmospheric $\mathrm{CO}_{2}$ levels has been biased on the conservative side, as shown in Table 1 . Subsequent analysis is based on the estimated range of mid-latitude (or average) global temperature change.

\section{Future fossil fuel $\mathrm{CO}_{2}$ release}

To assess trends over the next 50 years in global carbon dioxide build-up in the atmosphere, two plausible fossil fuel use scenarios have been devised. To establish an upper bound, global fossil fuel use to the year 2030 was assumed to follow current fossil energy use trends (average $4.3 \%$ increase per year). ${ }^{33}$ Fossil energy use is 
Figure 1. US and global contribution to total fossil-fuel-induced $\mathrm{CO}_{2}$ release.

Carbon release $\left(10^{9}\right.$ tonnes $\left.=10^{15} \mathrm{~g}\right)$ for high and low annual fossil fuel growth rate scenarios (see text) are displayed in terms of total (global) fossil fuel release and that due to coal combustion alone. The US share of coal and total fossil fuel release is shown for each case. Numbers next to the bars are the percentage of total carbon release for a given scenario and a given year. The contribution of world coal use to total carbon release increases in magnitude but remains constant in percentage, except in the high growth case for the period 2030. The percentage of US coal contribution remains relatively constant over the next 50 years for both scenarios, while total US fossil fuel contributions decline in percentage terms. Calculations of carbon release are based on the fossil fuel mix for each scenario using the conversion factors in Ref 42 and were made by $E$. Hail, Ref 51.

continued from $p 320$

annual atmospheric $\mathrm{CO}_{2}$ oscillations, hemispherical cycles due to temperatureinduced variations in ocean and sea ice. $\mathrm{CO}_{2}$ partial pressure, and seasonal cycles in winter heating are also noted.

${ }^{22} \mathrm{U}$. Siegenthaler and $\mathrm{H}$. Oeschger, Science, Vol 199, 1978, p 390 and J.R. Bray, Tellus, Vol 11, 1959, p 220.

${ }^{23} \mathrm{M}$. Stuiver, Science, Vol 199, 1978, $\mathrm{p}$ 258 and A.T. Wilson, Nature, Vol 273. $1978, p 41$.

${ }^{24}$ Keeling et al, op cit, Ref 17.

${ }^{25}$ Many reports ascribe major roles to naturai processes. In particular, H.L. Bohn \{Tellus, Vol 30, 1978, p 474\} suggests marked $\mathrm{CO}_{2}$ removal by peat soils in the order of $0.4 . \times 10^{9}$ tonnes carbon/year. K.E. Zimem (in Williams, op cit, Ref 8, p 94) also suggests that land carbonates may be a significant sink for carbon. Anthropogenic exchanges arise from creation of $\mathrm{CO}_{2}$ sources by deforestation, with attendant accelerated humus decay (B. Bolin, Science, Vol 196, 1977, p 613, Stuiver, op cit, Ref 23, p 258, Woodwell et al, op cit, Ref 20, pp 142-143 and Schlesinger, op cit, Ref 16, p 51. See the latter for a general review). $\mathrm{CO}_{2}$ sinks may be created by reforestation, by transforming wood products into structures, or possibly through enhanced photosynthesis due to increased atmospheric $\mathrm{CO}_{2}$ levels. Woodwell et al, ibid, p 144, Figure 3, summarize the disparate estimates for whether the terrestrial reservoir is a net source or sink for $\mathrm{CO}_{2}$

${ }^{26}$ Anthropogenic release of other gases, notably $\mathrm{N}_{2} \mathrm{O}$, aerosols, and chlorofluoromethanes, may compound global warming. As global temperature increases, the earth's albedo may change because of snow and ice melt. Also, with rising temperature, the water carrying continued on 322

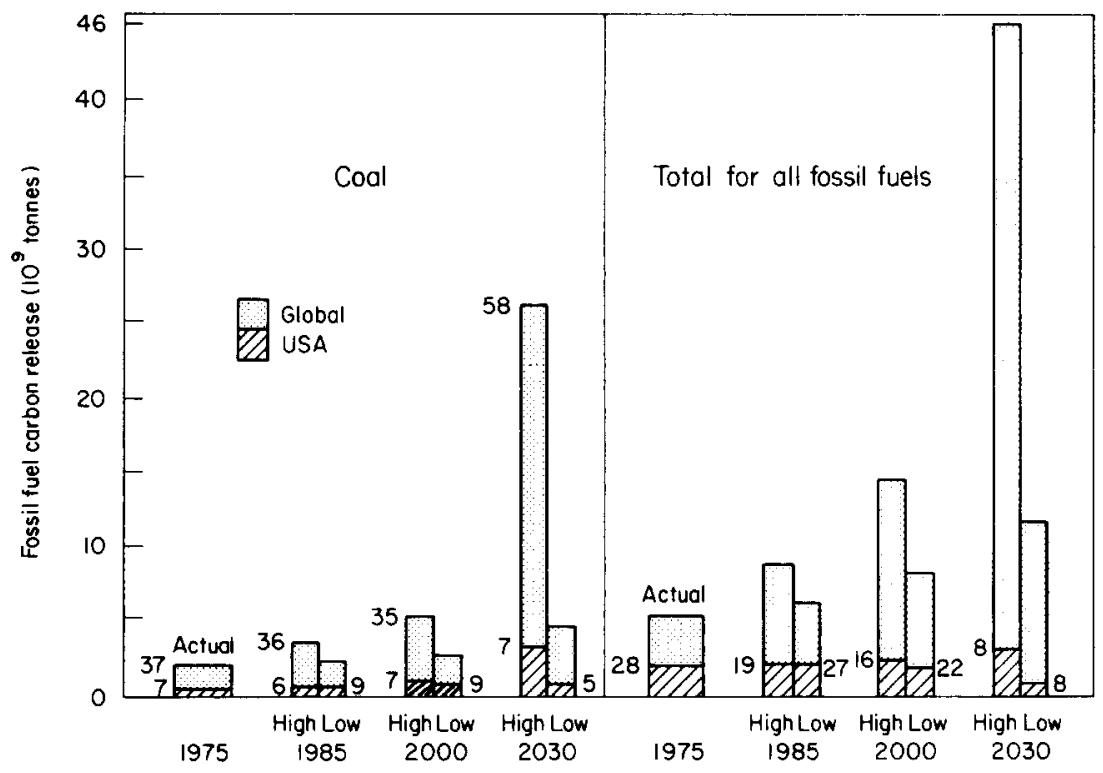

assumed to grow somewhat slower in the USA,${ }^{34}$ reaching 71 quads total ( 20 quads coal) by 1985,107 quads total ( 39 quads coal) by 2000 , and 144 quads total (129 quads coal) by $2030 . .^{35}$

To represent much lower growth in fossil energy use, another scenario was devised, which assumes that global fossil fuel energy use will grow at $2 \%$ per year, ${ }^{36}$ with the US growth rates the same as those for the high growth case for 1985 , slowing to $1 \%$ per year in 2000 (87 quads total, 30 quads coal) and to $-0.8 \%$ per year in 2030 (45 quads total, 25 quads coal). ${ }^{37}$

Figure 1 represents US and global contributions to world $\mathrm{CO}_{2}$ release based on these projected mixes for fossil fuels to the year 2030. In the high energy scenario, the US fossil fuel contribution to world $\mathrm{CO}_{2}$ release will peak around the year 2000 in absolute value and in percentage terms. The US contribution to global $\mathrm{CO}_{2}$ emissions is projected to decrease from $28 \%$ now to only $8 \%$ by 2030 in both of the scenarios. ${ }^{38}$

\section{Future temperature rise}

Each of the two growth scenarios has been analysed in terms of the following consistently optimistic and pessimistic scientific assumptions concerning mechanisms of the global carbon cycle. The optmistic assumptions (reflected in the lower bounds for both scenarios in Figure 2) are:

$40 \%$ of fossil fuel $\mathrm{CO}_{2}$ released remains in the atmosphere;

$2 \times 10^{9}$ tonnes carbon per year are subtracted from the atmosphere due to terrestrial uptake;

the lower limit of temperature rise (see Table 1) prevails.

The pessimistic assumptions (reflected in the upper bounds in Figure 2) are:

$60 \%$ of fossil fuel $\mathrm{CO}_{2}$ released remains in the atmosphere;

$1.2 \times 10^{9}$ tonnes carbon per year (net) are added to the atmosphere due to deforestation;

the upper limit of temperature rise prevails. ${ }^{39}$ 
Figure 2. Temperature range analysis.

See text for assumptions. System 'noise' is the natural variation in temperature and has been arbitrarily set at $1^{\circ} \mathrm{C}$ for our purposes.

\section{continued from $p 321$}

capacity of air increases, resulting in more cloud cover and uncertain temperature feedbacks. Moreover, particulates from fossil fuel combustion may screen out sunlight perhaps counteracting to some degree any warming trends due to $\mathrm{CO}_{2}$. Understanding of these compounding factors is fragmentary at present (Bach, op cit, Ref 8, p 146, H. Flohn, in Williams, ibid, pp 228-231 and K. Y. Kondratyev and A.M. Bunakova, in Williams, ibid, pp 204-205).

${ }^{27}$ B. Bolin, in Williams, ibid, p 42, Baes et al, op cit, Ref 18, p 314. Natural terrestrial/atmospheric exchanges primarily include the growth of plants and decay of humus. Other natural contributors to the global carbon cycle, such as weathering, volcanic emissions and sedimentation processes, have been excluded from the present analysis (see also, R.M. Garrells and E.A. Perry, in E.G. Goldberg, ed, The Sea, Wiley, New York, 1974. Vol 5. pp 303-306 and Siegenthaler and Oeschger, op cit, Ref 22, p 389).

${ }^{28}$ See Ref 25

${ }^{29}$ At the amosphere-ocean interface, the controversy is whether the oceans have absorbed the 'missing' anthropogenic $\mathrm{CO}_{2}$ and at what rate. Research based on ${ }^{14} \mathrm{C}$ isotope distributions between the surface and deep ocean have indicated a mixing rate of the order of thousands of years $(L$. Machta, in D. Dryssen and D. Jagner, eds. The Changing Chemistry of the Oceans, Wiley, New York, 1972, p 121, R. Bacastow and C.D. Keeling, in G.M. Woodwell and E.V. Pecan, eds, Carbon and the Biosphere. AEC Technical continued on $p 323$

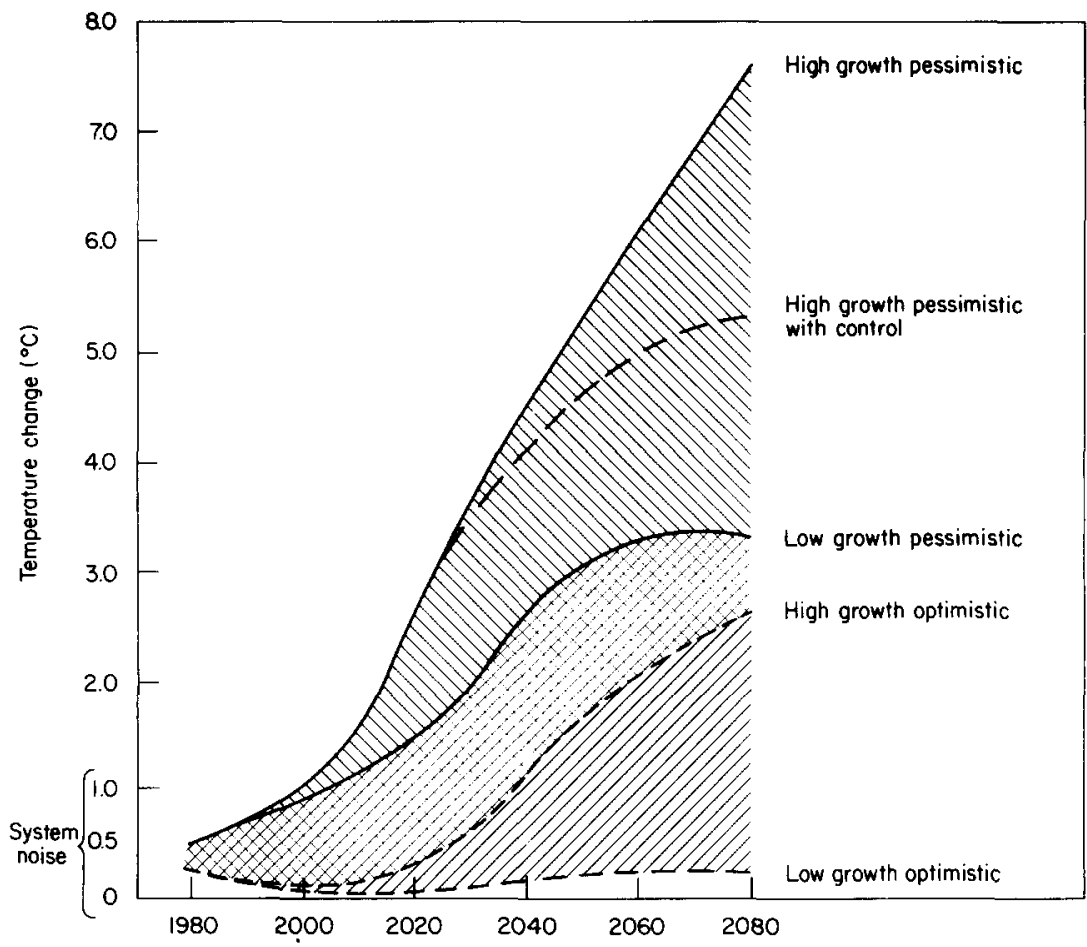

Thus four resulting combinations of energy growth rates and scientific assumptions concerning $\mathrm{CO}_{2}$ effects have been analysed.

Figure 2 shows the result of translating these scenarios, with their associated assumptions, into temperature changes over time. The bands of uncertainty in the two scenarios overlap considerably. The assumptions about the global carbon cycle affect projected temperature rises as much as future levels of fossil fuel use. While the earth's temperature in 1975 was measured and known, any warming effect of $\mathrm{CO}_{2}$ alone may have been offset by cooling trends due to other factors. ${ }^{40}$ This uncertainty is reflected in the difference in the 1978 values for the curves in Figure 2. For similar reasons, the optimistic curves show an initially negative slope, reflecting the possibility of the land biota acting as a $\mathrm{CO}_{2}$ sink before being overwhelmed by the $\mathrm{CO}_{2}$ release from increasing fossil fuel use.

\section{The potential for control}

Given the potential consequences of increased atmospheric carbon dioxide, we have investigated the feasibility of its reduction and control. No practical means for controlling $\mathrm{CO}_{2}$ has been demonstrated, though a number of concepts have been discussed. The salient difference between $\mathrm{CO}_{2}$ emissions and other pollutants is the staggering amount of $\mathrm{CO}_{2}$ generated, typically about $20 \%$ by weight of flue gas from coal fired power plants. Carbon dioxide control strategies can be classified according to:

- choice of fuels or energy technology;

capture;

storage;

conversion.

The effectiveness of $\mathrm{CO}_{2}$ control depends on the timing and extent of its implementation as well as the technical and economic feasibility of 
continued from $\mathrm{p} 322$

Information Center, Washington, DC, 1973, p 861). Yet G.M. Woodwell (in Williams, op cit, Ref 8, pp 65-66), W.S. Broecker (Science, Vol 189, 1975, p 461) and C.S. Wong (Science, Vol 200, 1978, p 199) have noted the likelihood of error in these estimates owing to the existence of short-term transfer phenomena, such as marine animal faecal pellet deposition or marine phytoplankton detritus on continental shelves with high sediment burial rates or anoxic environments. Siegenthaler and Oeschger lop cit, Ref 22, p 393) indicate 46 to $80 \%$ of the total produced $\mathrm{CO}_{2}$ would be retained in the atmosphere and would not be uptaken by the oceans 100 years from now, their upper limit being more 'pessimistic' than our assumptions (see text). The model of W.S. Broecker, Y.H. Li, and T.H. Peng (in D.W. Hood, ed, Impingement of Man on the Oceans, Wiley, New York, 1971, p 287) assumes an upper limit of $35 \pm 10 \%$ removal of $\mathrm{CO}_{2}$ produced, roughly equivalent to our upper limit.

${ }^{30}$ Manabe and Wetherald, op cit, Ref 3.

${ }^{31}$ Schneider, op cit, Ref 3.

${ }^{32}$ See Ref 25.

${ }^{33}$ See Baes et al, op cit, Ref 18. The highuse scenario assumes a reduction factor intended to characterize the impact of consumption on the global reserve as follows:

$$
\frac{1}{N} \frac{\mathrm{d} N}{\mathrm{~d} T}=0.043\left(1-\frac{N}{A}\right)
$$

where $N$ is the cumulative amount of fossil fuels consumed and $A$ is the global reserves (R.M. Rotty, in Williams, op cit, Ref $8, \mathrm{p} 269$ ). For our purposes, we have assumed 'free and easy' access $(x=1$ in Rotty's figure) to coal reserves and have omitted the exponent $x$ from the figure. Rotty shows curves for different values of $x$ (the emphasis on price, availability etc, as reserves become harder to extract). In all cases of $x$, the areas under Rotty's curves remain the same, difference between the curves being the period over which recoverable fossil fuels are being used and emitting $\mathrm{CO}_{2}$. Recoverable fossil fuels are estimated to contain $7.3 \mathrm{x}$ $10^{15} \mathrm{~kg}$ carbon. The low use scenario follows a symmetric reduction in consumption after the year 2025.

${ }^{34}$ See Ref 2 and US Environmental Protection Agency, Coal Technology Assessment: The First Year Report, prepared by Battelle Columbus Laboratories and the University of Michigan, in press.

${ }^{35}$ One quad $=10^{15} \mathrm{Btu}=10^{18}$ joules; 1 quad is the energy equivalent of more than 170 million barrels of crude oil.

${ }^{36}$ Baes, op cit, Ref 18.

${ }^{37}$ See Ref 34.

${ }^{38}$ This is also true in a scenario of high US energy use and moderate global energy use, perhaps a more likely case.

${ }^{39}$ Baes, op cit, Ref 18, p 315. J.S. Olson, personal communication, 1979, concurs that these ranges continue to be reasonable. See also Refs 27 and 29. the control technologies. While all fossil fuels and some solar energy technologies release $\mathrm{CO}_{2}$ to the atmosphere, we concentrate here on coal, as coal is considered by many to be the primary substitute for other fossil fuels as energy demand continues to grow. For example, global coal use contributes a third of the present fossil-fuel-related $\mathrm{CO}_{2}$ increase to the atmosphere, and this is expected to increase to about half by $2030 .^{41}$ However, determined efforts to control levels of atmospheric $\mathrm{CO}_{2}$ would require consideration of all sources of $\mathrm{CO}_{2}$ emissions.

\section{Choice of fuels and energy technology}

The choice of fossil fuel and the energy technology system through which it is used bear heavily on the amount of $\mathrm{CO}_{2}$ released. In terms of fuel alone, carbon released as $\mathrm{CO}_{2}$ per 100 quads of end use energy as heat through direct combustion is about $0.725 \times 10^{9}$ tonnes for natural gas, $1 \times 10^{9}$ tonnes for oil, and $1.25 \times 10^{9}$ tonnes for coal. ${ }^{42}$ In coal combustion, the amount of $\mathrm{CO}_{2}$ formed is directly related to the carbon content. Yet higher heat content accompanies increased carbon content in coal. Thus, typical lignite, sub-bituminous, and bituminous coals emit about the same amount of $\mathrm{CO}_{2}$ per unit of heat content, in a ratio of $1: 1: 0.94$, respectively. ${ }^{43}$ In coal combustion, $\mathrm{CO}_{2}$ emissions cannot be appreciably reduced by choice of feedstock.

Considerable differences exist in the amount of $\mathrm{CO}_{2}$ emitted and fossil fuel consumed by different energy technology systems when extraction, production, distribution, reconversion, and end use are all included. As shown in Table 2, different systems have different overall efficiencies and thereby release different amounts of $\mathrm{CO}_{2}$, while delivering equal amounts of end use energy. Table 2 indicates that without $\mathrm{CO}_{2}$ control, system 6 (coal liquefaction with boiler, producing electricity and then space heat) releases roughly twice as much $\mathrm{CO}_{2}$ as system 7 (high Btu gasification plus furnace) or system 8 (liquefaction plus furnace) in producing equal amounts of end use energy. In electricity generation, fluidized bed combustion, low sulphur coal, physically cleaned coal, and conventional boilers with limestone scrubbing, are all roughly equivalent in terms of amounts of $\mathrm{CO}_{2}$ released, producing about 300 million tonnes of $\mathrm{CO}_{2}$ per quad. Thus, synthetic fuels used to generate electricity appear less attractive than conventional fuels since $\mathrm{CO}_{2}$ emissions are higher. Also, the difference in $\mathrm{CO}_{2}$ release is about 2.3 times greater for synthetic fuels relative to natural gas for electricity generation, ${ }^{44}$ or about $50 \%$ higher than direct combustion of coal. While this appears to make synthetic fuels derived from coal less attractive, large numbers of synthetic fuel facilities are not likely in the short term and even so will only represent a relatively small proportion of global fossil fuel consumption over the next few decades. Moreover, synfuels for furnace use to provide space heat release less $\mathrm{CO}_{2}$ than does direct combustion of coal for electric space heat (see Table 2).

\section{$\mathrm{CO}_{2}$ capture}

Increased costs, efficiency losses and problems of acceptance make the application of $\mathrm{CO}_{2}$ control technology questionable. Nevertheless, the most likely control points for capturing $\mathrm{CO}_{2}$ are the stacks of fossil fuel power plants and industrial plants because of their relatively high concentration of $\mathrm{CO}_{2}{ }^{45}$ Two basic processes have been considered for capturing $\mathrm{CO}_{2}$ at stacks: aqueous potassium carbonate 


\begin{tabular}{|c|c|c|c|}
\hline System ${ }^{a, b}$ & Efficiency $^{c}$ & $\begin{array}{l}\text { Coal consumed } \\
\left(10^{13} \mathrm{~g} / \text { year }\right)\end{array}$ & $\begin{array}{l}\mathrm{CO}_{2} \text { emitted }^{\mathrm{C}} \\
\left(10^{13} \mathrm{~g} / \text { year }\right)\end{array}$ \\
\hline \multicolumn{4}{|l|}{ Without $\mathrm{CO}_{2}$ control } \\
\hline $\begin{array}{l}\text { Electricity generation } \\
\text { Direct } \\
1 \text { Low sulphur coal }\end{array}$ & & & \\
\hline \multicolumn{4}{|l|}{1 Low sulphur coal } \\
\hline 2 Physical coal cleaning & 0.9 (cleaning) & & \\
\hline $\begin{array}{l}\text { with boiler (PCC) } \\
3 \text { Fluidized bed }\end{array}$ & 0.37 (boiler) & 13 & 31 \\
\hline \multicolumn{4}{|l|}{4 Boiler with limestone } \\
\hline scrubber & 0.35 & 12 & 29 \\
\hline \multicolumn{4}{|l|}{ Synfuels } \\
\hline $\begin{array}{l}5 \text { Low Btu gasification } \\
\text { with combined cycle }\end{array}$ & $\begin{array}{l}0.70 \text { (gasification) } \\
0.40 \text { (combined }\end{array}$ & 15 & 36 \\
\hline \multirow{2}{*}{$\begin{array}{l}6 \text { Liquefaction with } \\
\text { boiler }\end{array}$} & 0.625 (liquefaction) & & \\
\hline & \multicolumn{3}{|c|}{ Furnace use } \\
\hline \multirow[t]{2}{*}{7 High Btu gasification } & $\begin{array}{l}0.65 \text { (gasification) } \\
0.97 \text { (pipeline) }\end{array}$ & & \\
\hline & 0.64 (furnace) & 9 & 22 \\
\hline $\begin{array}{l}8 \text { Liquefaction (assuming } \\
\text { short haul in lorry) }\end{array}$ & $\begin{array}{l}0.625 \text { (liquefaction) } \\
1.0 \text { (transportation) } \\
0.60 \text { (furnace) }\end{array}$ & 10 & 24 \\
\hline \multicolumn{4}{|l|}{ With $\mathrm{CO}_{2}$ control } \\
\hline $\begin{array}{l}1 \text { Low sulphur coal boiler } \\
\text { for electricity } \\
7 \text { High Btu gasification for } \\
\text { furnace use }\end{array}$ & $\begin{array}{l}0.27 \text { (control point) } \\
0.62 \text { (gasification - } \\
\quad \text { control point) } \\
0.97 \text { (pipeline) } \\
0.64 \text { (furnace) }\end{array}$ & 16 & $1^{e}$ \\
\hline
\end{tabular}

a Systems 1-6 assume electrical transmission efficiency of 0.912 and application efficiency (not heat pump) of 0.98 .

b Bituminous coal feed assumed.

c Efficiency loss assumptions for $\mathrm{CO}_{2}$ disposal have been included for the controlled systems.

d More $\mathrm{CO}_{2}$ (dryweight) is produced than coal feed. Increase reflects the higher molecular weight of $\mathrm{CO}_{2}$ over carbon, the carbon content of the coal, and the high percentage of reacted carbon when coal is combusted.

e Theoretically $100 \%$ control is possible. This figure, however, represents optimistic system reliability

Note: All figures have been rounded.

Source: E. Hall, Ref 51, based on Ref 43 .

${ }^{40}$ J.M. Mitchell, Quarterly Research, Vol $2,1972, \mathrm{p} 436$ and W.S. Broecker, op cit, Ref 29. See also Ref 25.

${ }^{41}$ See Ref 33.

${ }^{42}$ C.D. Keeling, Tellus, Vol 25, 1973. The conversion factors for coal, oil, and natural gas used were $25.4 \mathrm{~kg}, 20.0 \mathrm{~kg}$, and $14.4 \mathrm{~kg}$ carbon released per $10^{9}$ joules (J) input, respectively.

${ }^{43}$ American Gas Association, Carbon Dioxide Emissions from Fossil Fuel Combustion and from Coal Gasification. Energy Analysis, Arlington, VA, 1977, p 4, Table 2. These figures differ from the conversion factors in Ref 42 roughly by the difference in molecular weight of $\mathrm{CO}_{2}$ over carbon. For comparison, methane emits $52 \mathrm{~kg} \mathrm{CO} \mathrm{CO}_{2}$ per $10^{9} \mathrm{~J}$ and petrol emits $73 \mathrm{~kg} \mathrm{CO} 2$ per $10^{9} \mathrm{~J}$

${ }^{44}$ G.M. Woodwell, G.J. MacDonald, R. Revelle and C. David Keeling. The Carbon Dioxide Problem: Implications for Policy in the Management of Energy and Other Resources, a report to the Council on Environmental Quality, 1979.

${ }^{45} \mathrm{~A}$. Albanese and $\mathrm{M}$. Steinberg. Environmental Control Technology for Atmospheric Carbon Dioxide, BNL50877. Brookhaven National Laboratory, Upton, NY, 1978, p 7, C. Marchetti, Climatic Change, Vol 1, 1977, p 61 and continued on $p 325$ scrubbing and cryogenic separation. The former is thought to reduce significantly power plant efficiency (from $37 \%$ to $30 \%$ net energy output) and to be expensive, possibly doubling the capital cost of power plants to capture all of the $\mathrm{CO}_{2}{ }^{46}$ The cryogenic separation process uses more energy for $\mathrm{CO}_{2}$ capture than the plant produces (net energy loss). ${ }^{47}$

\section{$\mathrm{CO}_{2}$ storage}

Two media are possible for $\mathrm{CO}_{2}$ storage: oceanic and terrestrial. $\mathrm{CO}_{2}$ may be stored terrestrially in many formations, both natural and man-made.

The deep ocean may be the only realistic storage medium as it has an enormous capacity and it already provides a natural permanent sink for $\mathrm{CO}_{2}$ (after the natural conversion of $\mathrm{CO}_{2}$ by seawater to a stable carbonate). However, the long-term implications of such storage are unknown. Storage in salt domes or through injection into oilfields for enhanced oil recovery have also been considered. However, estimated total capacity for such storage is small (optimistically about $20 \%$ of one current year's global release of $\mathrm{CO}_{2}$, or even a smaller percentage for a future year's production). ${ }^{48}$ In any event, disposal of $\mathrm{CO}_{2}$ will require additional energy: up to $10 \%$ of the net output from a coal fired power plant. ${ }^{49}$

\section{$\mathrm{CO}_{2}$ conversion.}

The methods of $\mathrm{CO}_{2}$ conversion which have received most attention 
are reforestation and general fertilization of existing forests. However, costs in terms of capital and redistribution of resources makes them impractical short of a $\mathrm{CO}_{2}$ related global emergency. ${ }^{50}$

An alternative biological approach is to convert flue gas $\mathrm{CO}_{2}$ using on-site control technologies. Two possibilities are bacterial action, which converts $\mathrm{CO}_{2}$ to methane using biogas generators, and construction of greenhouse environments. Again, such conversion would be limited by capital and resource costs. ${ }^{51}$ Also, use of plant material as biomass for energy would only have a transient conversion effect, as the stored carbon would eventually be released to the atmosphere when the biomass was processed.

Another method for converting recovered $\mathrm{CO}_{2}$ to synthetic liquid and gaseous carbonaceous fuels using nuclear reactors has been investigated. ${ }^{52}$ Here the energy requirements clearly favour direct use of the nuclear capacity for energy production.

\section{Potential effectiveness of control}

We have chosen $\mathrm{CO}_{2}$ capture by scrubbing with disposal in the deep ocean as the most feasible control alternative for the present. Centralized conversion facilities would be the most amenable to this control approach. A comparison of systems 1 and 7 in Table 2, with and without $\mathrm{CO}_{2}$ control technology, illustrates this point. Without control technology, system 7 , syngas for furnace use, is more efficient and therefore produces less $\mathrm{CO}_{2}$. With control technology, system 1, direct combustion for electric space heat, produces more $\mathrm{CO}_{2}$ but is more amenable to control, thus releasing less $\mathrm{CO}_{2}$ overall to the atmosphere.

The efficiency and economic penalties of applying $\mathrm{CO}_{2}$ control

continued from $p 324$

Mustacchi, P. Armenante and V. Cena, in Williams, op cit, Ref 8, p 289

${ }^{46} \mathrm{M}$. Steinberg. A.S. Albanese and V.D. Dang. 'Environmental control technology for carbon dioxide', paper presented at the 71 st American Institute of Chemical Engineers Annual Meeting, Miami, FL, 1978, p 29. C. Mustacchi, et al, in Williams, ibid, p 287, Marchetti, ibid, p 65, J. Patton, Energy Communications, Vol 4, 1978, p 3 and A. Albanese, followup report to Coal Technology Assessment $\mathrm{CO}_{2}$ Forum, December 1978. Participants of the latter forum included: A. Albanese, S.K. Atreya, D.E. Briggs, K. Chen, T. DeHudy, W. Emanuel, D. Gates, R. Letcher, O. Markley, D. Michael, K. Shea, W. Sheppard, and R. Winter.

${ }^{47}$ Mustacchi, ibid and Steinberg et al, ibid.

48 Patton, op cit, Ref 46, Steinberg et al, ibid, p 15 and $\mathrm{p} 25$ and Marchetti, op cit. Ref 45, pp 64-65.

49 Albanese, op cit, Ref 46.

${ }^{50} \mathrm{~F}$. Dyson, Energy, Vol 1, 1977, p 3.

${ }^{51}$ E. Hall, personal communication, 1978.

52 Steinberg et al, op cit, Ref 46.

${ }^{53}$ Our reasons for this assumption are: the impracticality of total applications of $\mathrm{CO}_{2}$ control technology in certain energy systems, such as small industrial boilers; reluctance to apply control technology because of efficiency losses and capital costs (especially in developing countries): and incomplete $\mathrm{CO}_{2}$ capture where control technology is applied. technology suggest its consideration only if $\mathrm{CO}_{2}$ effects are indeed severe, as shown by the 'high growth pessimistic' case in Figure 2. Our evaluation of the potential effectiveness of control is based on the following assumptions:

- No large-scale application of $\mathrm{CO}_{2}$ control technology will be accepted as necessary until the average global temperature rise reaches $1{ }^{\circ} \mathrm{C}$, corresponding to the 'high growth pessimistic' case around 2000. A temperature rise of this magnitude would be required to separate a $\mathrm{CO}_{2}$-induced signal from the 'noise' of natural temperature fluctuations.

- No $\mathrm{CO}_{2}$ control technology will be applied to energy systems using oil and natural gas as the primary fossil fuels as they are expected to be used in the future mostly for decentralized energy systems such as cars and home heating.

- No more than $25 \%$ of the $\mathrm{CO}_{2}$ released by combustion of coal will be captured by $\mathrm{CO}_{2}$ control technology. ${ }^{53}$

- About 20 years will be required for $\mathrm{CO}_{2}$ control technology to saturate its potential applications.

- Carbon dioxide storage has not been assumed to be limiting, apart from possible efficiency losses.

These assumptions give the benefit of the doubt to the application of $\mathrm{CO}_{2}$ control technology. Combining these assumptions with the "high growth pessimistic' case, we obtain the 'with control' curve in Figure 2 . The effect of control does not appear to be very pronounced in the period 2000-2030 because coal will just be beginning to overtake oil and natural gas and time is required for the diffusion of the control 
54 Gates, op cit, Ref 1.

${ }^{55}$ For descriptions of plausible low energy scenarios see: G. Leach, C. Lewis, F. Romig, A. van Buren and G. Foley, A Low Energy Strategy for the United Kingdom. International Institute for Environment and Development and Science Reviews, London, 1979; A.B. Lovins, Soft Energy Paths: Toward a Durable Peace, Friends of the Earth/Ballinger, Cambridge, MA, 1977, and Harper and Row. New York, 1979; and J.S. Steinhart, M.E. Hanson, C.C. DeWinkel, R.W. Gates, K.A. Briody, M.D. Thornsjo and S.J. Kabala, A Low Energy Scenario for the United States: 1975-2050. Marine Studies Center and Instructional Program, Institute for Environmental Studies, University of Wisconsin-Madison, 1977.

${ }^{56}$ R.M. Rotty, in Williams, op cit, Ref $8, p$ 267.

57 World Energy Conference, Survey of Energy Resources 1974, Miller Freeman Publications, San Francisco, CA, 1975. See map of world coal resources and major trade routes.

58 /bid. technology. The net effect of control is to postpone the impact of $\mathrm{CO}_{2}$ for a few years. Beyond the year 2030, with oil and natural gas use decreasing, application of $\mathrm{CO}_{2}$ control technology could be equivalent to cutting fossil fuel use by a quarter. With the nearly exponential growth of coal use in the high growth scenario, control technology by itself does not appear capable of restricting $\mathrm{CO}_{2}$ build-up.

\section{Policy considerations}

The temperature range analysis in Figure 2 indicates that for the present, the only justification for immediate curtailment of coal or fossil fuel use on the grounds of $\mathrm{CO}_{2}$ effects alone would be evidence that even a small temperature change is unacceptable and that such a change is occurring or imminent. Yet it would not be prudent for policy makers to postpone considering policy options regarding the $\mathrm{CO}_{2}$ issue until the uncertainties disappear. ${ }^{54}$ Given the potential effects of $\mathrm{CO}_{2}$, contingency plans and near-term actions should be considered.

\section{Contingency plans}

There need to be at least two basic components in global contingency plans: curtailment of fossil fuel use, and application of $\mathrm{CO}_{2}$ control technology. Both components imply radical departure from past and present trends. Implementation of such plans should not be recommended unless $\mathrm{CO}_{2}$ effects are clearly detrimental, for successful implementation cannot occur without global support.

Curtailment of fossil fuel use implies a drastic reduction in growth of energy use and emphasis on other energy supply alternatives (notably solar, geothermal, or nuclear). A significant shift to nuclear energy will not be easy because of scarcity of resources including capital and fuel, increasing worldwide concern about nuclear safety, and problems of radioactive waste disposal. In the absence of major changes in attitudes toward and support for energy alternatives such as solar or geothermal, prospects for significant contributions from non-fossil-fuel energy sources are not great in the near term. Reducing growth in the annual energy consumption will be even more difficult in the absence of a successful global movement to a low energy path, ${ }^{55}$ since it implies a drastic change in lifestyle in the developed nations and possibly a denial of economic growth to many developing countries. Furthermore, application of $\mathrm{CO}_{2}$ control technology, if successful, could only postpone potential consequences of $\mathrm{CO}_{2}$ effects for a few years.

No country alone can keep global $\mathrm{CO}_{2}$ effects within inconsequential limits if the rest of the world follows a high fossil fuel use scenario. Presently, the USA contributes $28 \%$ to the worldwide atmospheric $\mathrm{CO}_{2}$ burden from fossil fuel energy use; other industrialized nations, including the USSR, Japan, Canada, Australia, New Zealand, and those in western and eastern Europe, contribute $53 \%{ }^{56}$ Africa and South America combined contain less than one percent of total known coal reserves; ${ }^{57}$ apart from Australia and South Africa, no significant reserves of coal have been found in the Southern Hemisphere. The USA, USSR and China, which between them control about three-quarters of the world's known coal reserves, ${ }^{58}$ could negotiate some kind of three-way agreement, analogous to arms limitation, to limit coal use and apply $\mathrm{CO}_{2}$ control 
technology if and when $\mathrm{CO}_{2}$ effects become clearly significant. Such negotiations would be very complicated for many reasons, not the least of which would be that trilateral agreements to limit coal exports from these nations could exacerbate tensions with the fossil-fuel-poor developing countries.

Since uncertainty about $\mathrm{CO}_{2}$ will not disappear in the near term, there is no clearly favourable time for implementing contingency plans. First, particularly in the coal case, $\mathrm{CO}_{2}$ effects are far less certain than other environmental problems of coal use such as acid rain, particulates, toxic substances, strip mine reclamation, and water shortages. And even if $\mathrm{CO}_{2}$ effects become certain, they appear to be far in the future - at least 20 to 50 years away - which lends credence to arguments that technical solutions can be found in time to prevent the anticipated problems. The decreasing relative contribution to global $\mathrm{CO}_{2}$ release by the USA does not exempt it from the need to be concerned about $\mathrm{CO}_{2}$ effects, although the fact that the USA cannot resolve the $\mathrm{CO}_{2}$ problem unilaterally may deter US policy makers from active consideration of measures to deal with it. Finally, successful implementation of contingency plans will require global support and cooperation which is extremely unlikely as long as industrialized nations continue to use a disproportionate share of fossil fuels. Moreover, some nations may benefit from $\mathrm{CO}_{2}$ effects. ${ }^{59}$

\section{The time to act}

If no drastic action is likely to be taken until the global community is sufficiently convinced of the relative certainty and urgency of $\mathrm{CO}_{2}$ effects (and if they do not feel helpless in the face of such a complex problem), ${ }^{60}$ when would it be too late to act?

We explored this question on the basis of the curve corresponding to the 'high growth pessimistic' case in Figure 2 . The relative certainty of $\mathrm{CO}_{2}$ effects may not be convincing to the public until the global average temperature rises above the 'noise' level of $1^{\circ} \mathrm{C}$, or around the year 2000. If large-scale application of $\mathrm{CO}_{2}$ control technologies starts in the year 2000, average global temperature rise cannot be held to less than $3^{\circ} \mathrm{C}$ (an increase at which dire consequences of $\mathrm{CO}_{2}$ effects are plausible) by the year 2030. Control technology alone simply will not do the job. If the pessimistic assumptions hold as well for the low growth case, the average global temperature rise would still reach the dangerous level of $3^{\circ} \mathrm{C}$ in 75 years. Thus, in the pessimistic case, a combination of curtailment of fossil fuel use and $\mathrm{CO}_{2}$ control will be needed, starting by the year 2000 , to ward off the consequences of $\mathrm{CO}_{2}$ effects.

\section{A framework for uncertainties}

Placing the uncertainties concerning timely implementation of contingency plans in a rational framework can help highlight the risks

${ }^{59}$ Kellogg, op cit, Ref 5 .

$60 \mathrm{~J}$. Shorett, personal communication, 1979.

${ }^{61}$ Calculations for a number of sets of probabilities and utilities are available from the authors. To be consistent, $p_{1}=$ $p_{2} p_{3}+\left(1-p_{2}\right) p_{4}$. That is, the marginal probability of $\mathrm{CO}_{2}$ effects being hazardous, as perceived now, should be the same regardless of what the mean global temperature rise turns out to be later. involved. One such framework is illustrated by the decision tree in Figure 3, with its assigned subjective probabilities, $p_{i}$, and utilities, $u_{j}$. Manipulating the probabilities and utilities in the decision tree supports the following observations: ${ }^{61}$

- the longer decisions are delayed, the higher the probability of making a 'correct' decision;

- the longer decisions are delayed, the less likely the implementation of contingency plans, if required, would be effective; 


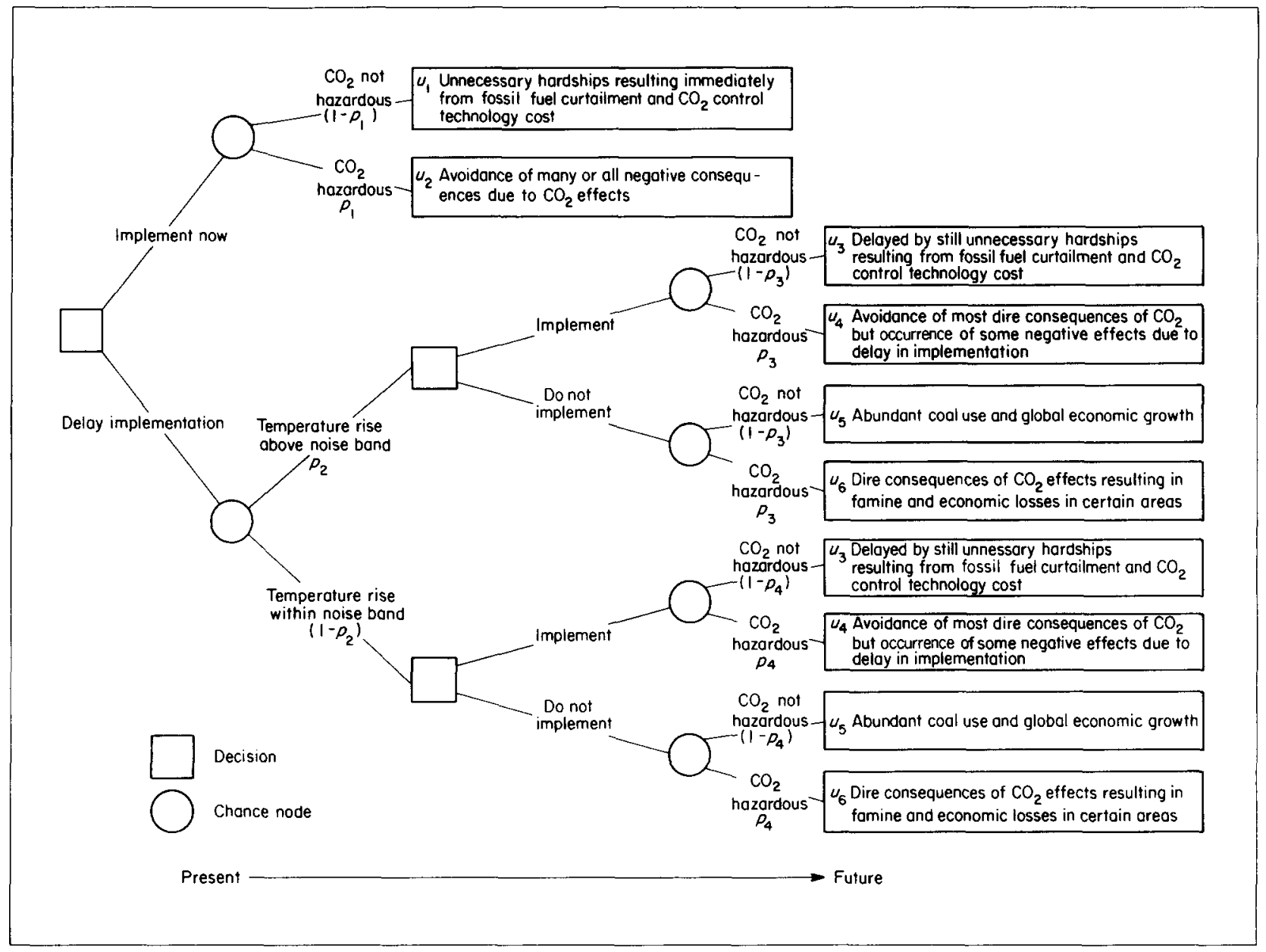

Figure 3. Decision tree for implementing $\mathrm{CO}_{2}$ contingency plans. The symbols $p_{i}$ and $u_{i}$ represent subjective probabilities and utilities respectively. Decisions regarding possible $\mathrm{CO}_{2}$ effects have a dynamic nature because of the likelihood of increased knowledge in the future and the long lead times required to implement contingency plans successfully. See discussion in text and Ref 61.
${ }^{62}$ M. Glantz, Nature, Vol 280, 1979, $p$ 189.

${ }^{63}$ K.R. Hammond, Judgement and Decision in Public Policy Formation, Westview Press, Boulder, CO, 1978, pp $15-24$.
- the higher the temperature rise necessary to convince the general public and decision makers that a $\mathrm{CO}_{2}$-induced warming may be occurring, the later decisions to implement contingency plans would be made;

- the less understood possible $\mathrm{CO}_{2}$ impacts may be, or the more hopeless the situation seems, the greater the likelihood that 'business as usual' outcomes will be assigned greater utility over potential $\mathrm{CO}_{2}$-induced consequences.

\section{Near-term actions}

While contingency plans should be developed for collaborative implementation by the international community at some future time, meaningful actions can be taken now in conservation, augmented research, monitoring efforts, and global education about $\mathrm{CO}_{2}$ effects.

Past research has focused on the physical and biological aspects of the global carbon cycle. In spite of uncertainties which exist, research on the social, economic, and political impacts of possible regional and global $\mathrm{CO}_{2}$-induced climatic changes should be started. Such research is essential to define the potential dimensions and magnitude of the problem. ${ }^{62}$ Since policy decisions can be, and usually are, analysed in the face of uncertainty, decision analysis could be used to help assess these research programmes and set research priorities in order to reduce critical uncertainties for policy decisions. ${ }^{63}$ Moreover, support 
of $\mathrm{CO}_{2}$ research should be assured long-term continuity in order to attract and maintain capable and experienced investigators. ${ }^{64}$

Crucial to early warning about possible $\mathrm{CO}_{2}$ effects is a comprehensive monitoring effort to allow recognition of $\mathrm{CO}_{2}$ effects. Such an effort would have two principal aspects. The first relates to monitoring possible temperature and climatic changes. Because temperature changes would be magnified at the poles, the higher latitudes may provide the earliest indications of change. Remote sensing capabilities already exist for monitoring sea ice changes and recessions or surges in sensitive formations such as the West Antarctica ice sheet. ${ }^{65} \mathrm{~A}$ network of soil temperature sensors in impermeable rock (to eliminate compounding water effects) coupled with atmospheric $\mathrm{CO}_{2}$ monitors could forewarn of small but perceptible temperature trends. ${ }^{66}$ Judicious choices would be needed for placement of monitors to compensate for possible wind pattern shifts under conditions of changing climate. Ocean current patterns at higher latitudes may also be sensitive to slight temperature changes and might lend themselves to monitoring. Remote sensing of vegetational shifts, particularly tundra, and snow lines at lower latitudes could also provide early warning.

The second aspect of $\mathrm{CO}_{2}$ monitoring involves social attitudes. Relative scientific certainty without broadly based public agreement would mean inaction. What degree of temperature change would convince sufficient people that climatic warming was occurring and thus bring about action? Which countries would have the most to gain or lose from effective response to $\mathrm{CO}_{2}$ ? How does the importance of climatic change rank compared to other human values? Which regions would be most instrumental in supporting or changing perceptions concerning climatic warming? Which social indicators can policy makers rely upon to assess the political feasibility and effectiveness of implementing contingency plans to alleviate $\mathrm{CO}_{2}$ effects? How is this likely to change over time? These are all questions related to social attitudes which should be monitored.

The high degree of uncertainty, a potential for global consequences, the probability of having 'winners' and 'losers', an inability of any nation to 'solve' the problem alone, the need for new levels of international cooperation not only to identify the problem but also to act upon it, the complexity of the problem, and the feeling of helplessness in avoiding the potential consequences of increasing levels of atmospheric $\mathrm{CO}_{2}$ place it among the set of 'the tragedy of the commons' ${ }^{\prime 7}$ problems that seem to be emerging with increasing frequency. Such problems both require and provide opportunities for learning new ways of problem solving as a global society. ${ }^{68} \mathrm{We}$ need to develop and provide the resources necessary to address problems of this kind.

Such problems can be approached in four steps, of increasing effectiveness: ${ }^{69}$

64 M. Glantz, op cit, Ref 62, p 190.

65 Mercer, op cit, Ref 3.

66 Gates, op cit, Ref 1.

${ }^{67} \mathrm{G}$. Hardin, Science, Vol 162, 1968, pp $1243-1248$.

68 D. Michael, personal communication. 1978.

${ }^{69}$ O.W. Markley, personal communication, 1978 . compensatory - paying for the damage;

ameliorative - replacing or substituting for that which is damaged;

- preventive - not allowing damage to occur;

- systemic - changing the mode and process of problem solving or redefining the problem in a categorically different fashion.

Clearly, if the pessimistic projections in Figure 2 are correct, it is too 


\footnotetext{
${ }^{70}$ This could include developing new strains of crops capable of adjusting to different climates or greater variations in climate, massive transfer of agricultural production, reorganizing food distribution networks, damming coastal areas against inundation, and moving people to areas capable of supporting them. These ameliorative efforts would require systemic changes in global behaviour.
}

late to compensate for or prevent some aspects of $\mathrm{CO}_{2}$ effects. Contingency plans could help alleviate $\mathrm{CO}_{2}$ effects if the global community chooses to act quickly and if $\mathrm{a} \mathrm{CO}_{2}$-related warming trend is identified. Carbon dioxide effects could be lessened, to some extent, by adapting to them. ${ }^{70}$

Perhaps the only real option available is for the global community to learn to live with a warmer climate. The challenge thus becomes to find adequate forums to foster such learning. International conferences have already been held, involving members of the scientific community. More conferences of this kind and exchanges of ideas between policy makers, educators and opinion makers drawn from a broad representation across national and ideological boundaries must take place in the future.

\section{Conclusions}

Uncertainty about the $\mathrm{CO}_{2}$ problem is so great that the range of predictions varies from one extreme to the other. If the world follows the high fossil fuel use scenario, a $2^{\circ} \mathrm{C}$ average temperature rise (close to $10^{\circ} \mathrm{C}$ near the polar regions) could occur within 35 years with pessimistic assumptions or within 75 years with optimistic assumptions. Under conditions of low energy growth rates and pessimistic assumptions, such a rise may occur within 50 years. Only with low growth and optimistic assumptions will a noticeable temperature rise not occur over the next century.

The choice of fossil fuel technologies, particularly coal use, would make some difference in the amount of $\mathrm{CO}_{2}$ released due to differences in overall efficiency and in amenability to control. $\mathrm{CO}_{2}$ control technology appears technically feasible. Yet even if problems of cost and attitudes could be overcome, control technology could at best buy time but could not by itself restrict $\mathrm{CO}_{2}$ limits. Thus, the fundamental problem becomes how to develop effective contingency plans now and implement them on an appropriate scale when needed.

Prudence dictates that plans should be made for the worst case. Desirable near-term actions include research strategies to reduce critical uncertainties for policy decisions, monitoring the $\mathrm{CO}_{2}$ problem on the basis of a number of physical and social indicators, and starting a global learning process involving not only policy makers, educators, opinion makers, and scientific reserachers, but also the general public who will have to be involved if efforts to deal with the problems related to increasing levels of atmospheric $\mathrm{CO}_{2}$ are to be effective. Above all, feasibility in near-term energy choices and fostering conservation of forests and energy should be emphasized.

Coal and, to a lesser extent, nuclear power are considered by many to be the most abundant energy resources for the foreseeable future. Whether they play a permanent or only a transitional role before solar and fusion power can supply most of the world's total energy needs is yet to be determined. $\mathrm{CO}_{2}$ effects of fossil fuel use on the one hand and radioactive wastes from nuclear power on the other are the jaws of an environmental vice in which humanity finds itself caught as the world consumes more and more energy. Unless and until the entire global community is fully aware of this long-term problem and learns how to act together toward its resolution, humanity may be in great peril. 